\title{
Is the type of soil an important factor determining the local abundance of carrion beetles (Coleoptera: Silphidae)?
}

\author{
PAVEL JAKUBEC and JAN RŮŽIČKA \\ Department of Ecology, Faculty of Environmental Sciences, Czech University of Life Sciences Prague, Kamýcká 129, \\ CZ-165 21 Prague 6 - Suchdol, Czech Republic; e-mails: jakubecp@fzp.czu.cz; ruzickajan@fzp.czu.cz
}

Key words. Coleoptera, Silphidae, Nicrophorinae, Silphinae, ecology, burying beetles, soil type, chernozem, fluvisol, diversity

\begin{abstract}
Carrion beetles (Coleoptera: Silphidae) provide a valuable ecosystem service by promoting nutrient cycling and controlling pests like noxious flies (Diptera: Calliphoridae and Sarcophagidae). Our main goal was to examine the relationship between the occurrence of carrion beetles and soil type. We used pitfall traps to collect 43,856 specimens of 15 species of carrion beetles in the Czech Republic during 2009. We found that the abundance of seven of the carrion beetles - Nicrophorus antennatus (Reitter), N. germanicus (Linnaeus), N. humator (Gleditsch), N. interruptus (Stephens), N. sepultor (Charpentier), Silpha obscura obscura (Herbst) and T. sinuatus (Fabricius) - was significantly higher either in areas with chernozem or fluvisol soils. These findings support our hypothesis that soil type could be an important factor determining the occurrence of necrophagous European carrion beetles. Our findings could be helpful when selecting important nature conservation sites (particularly inasmuch as $N$. antennatus, $N$. germanicus and $N$. sepultor are listed as endangered species on the Czech Red List of Invertebrates) as in this respect localities where there are chernozem soils are potentially valuable.
\end{abstract}

\section{INTRODUCTION}

The majority of carrion beetles (Coleoptera: Silphidae) are obligate carrion feeders. They are frequently associated with the corpses of vertebrates and provide a wide range of ecosystem services, such as promoting nutrient recycling and removing potential breeding sites of noxious flies (Diptera: Calliphoridae and Sarcophagidae), by effectively removing the corpses (burying beetles - Nicrophorinae) or eating fly larvae (Nicrophorinae and some Silphinae) (Anderson \& Peck, 1985; Sikes, 2008; Goff, 2009).

Despite their relatively low global species diversity (186 species), they occur widely throughout the Holarctic region (Sikes, 2008; Grebennikov \& Newton, 2012). Carrion beetles can be divided into two taxonomic groups, the subfamilies Silphinae and Nicrophorinae, which are morphologically and also ecologically different (Sikes, 2005). Burying beetles of the subfamily Nicrophorinae are well known for their biparental care, while beetles of the subfamily Silphinae do not manifest such behaviour (Peck \& Anderson, 1985a; Sikes \& Venables, 2013).

The phenology and habitat selection of carrion beetles have been intensively studied in recent years (e.g. Peck \& Anderson, 1985b; Creighton et al., 1993; Růžička, 1994; Lingafelter, 1995; Lomolino \& Creighton, 1996; Kočárek, 2001; Archer, 2003; Hocking et al., 2007; Mullins et al., 2013). The relationship between soil characteristics and the occurrence of carrion beetles is often mentioned in the literature, but this has been based only on the authors' observations and without appropriate statistical testing (Pukowski, 1933; Paulian, 1946; Theodorides \& Heerdt, 1952; Novák, 1961, 1962). The logical reason behind this hypothesis is that the developmental cycle of many carrion beetles is tightly connected with soil. For example Nicrophorinae bury the corpses of small vertebrates for breeding and Silphinae pupate underground. It has been proposed that a possible explanation for preferring a particular type of soil could be that some soils are better able to maintain a stable environment in terms of moisture and temperature, which is beneficial for the beetles (Novák, 1961, 1962). In a study of Nearctic insects, Looney et al. (2009) report that deep, loess soils host more abundant populations of necrophagous beetles than do shallow rocky soils. They also found that some species actually prefer shallow rocky soils to deep, loess soils. This niche differentiation could be due to interspecific competition (Anderson, 1982a; Bishop et al., 2002).

Detailed information about the biology of the different species can be used to identify important conservation sites for endangered carrion beetles, as Jurzenski et al. (2014) did for Nicrophorus americanus (Olivier).

Our field study is aimed at determining the habitat preferences of European open-landscape carrion beetles. Interspecific competition is discussed only in respect to other carrion beetles, because our trapping method was not designed for collecting other necrophagous invertebrates. We expected that most species of the subgenus Nicrophorus would be more abundant in areas where there are chernozem rather than fluvisol soils. Beetles of the subfamily Silphinae do not interact with the soil as closely as do Nicrophorinae, and we therefore had no reason to think that their abundance would differ in areas with chernozem or fluvisol soils. 


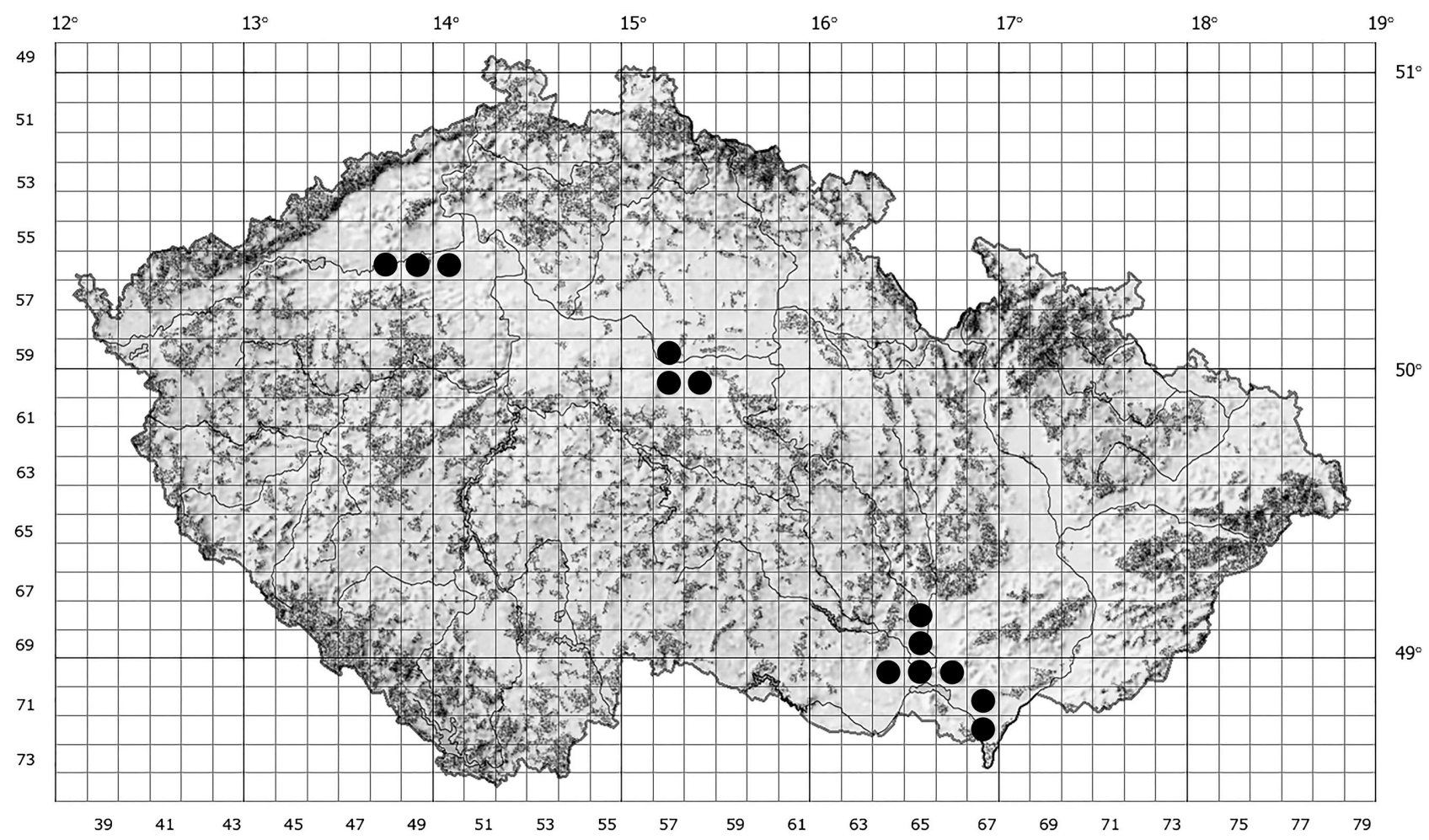

Fig. 1. Locations of the areas studied in the Czech Republic, which are indicated by black dots on a faunistic grid map (Jakubec \& Růžička, 2012).

\section{MATERIAL AND METHODS}

\section{Site selection}

This study was done during 2009 in the Czech Republic in regions with a similar medium warm (MT10) to very warm (T4) climate (Cenia, 2008) and similar occurrence of two different types of soil (chernozem and fluvisol) in open-landscape habitats. In order to select suitable locations, we uploaded data on climate, soil type and land use from a Cenia (2008) database into the geographical information system software ArcGIS 9.2 and looked for locations where these three conditions overlapped (ESRI, 2008). Accessibility was also taken into account.

We selected an equivalent number of locations on chernozem (33) and fluvisol (33) soils, which were clustered in three regions (see Fig. 1). These locations were at least $1.5 \mathrm{~km}$ apart, and we arranged them more or less while alternating linearly between sites on fluvisol and chernozem soils as in Fig. 2. There is a detailed description of the sites in Jakubec \& Růžička (2012).

\section{Trapping}

For collecting beetles, we used baited pitfall traps designed by Růžička (2007), which were made from $1,080 \mathrm{ml}$ plastic buckets (opening of $103 \mathrm{~mm}$ and $117 \mathrm{~mm}$ deep). These traps were part filled with a preservation solution of $200 \mathrm{ml}$ water and $100 \mathrm{ml}$ ethylene glycol. Traps were covered with a net of $2 \mathrm{~cm}$ mesh and an aluminum roof as protection against scavenging animals and flooding by rain. Frozen fish meat (cod) and ripening cheese (Romadur) were used as bait, placed in a small container $(Q 5 \mathrm{~cm}$ and $1.5 \mathrm{~cm}$ deep) and hung above the preservation solution.

A line of five traps was established at each location. The distance between these traps was at least $20 \mathrm{~m}$. They were placed within one continuous agricultural field, and no closer than $50 \mathrm{~m}$ from the edge of the field. In an attempt to minimize the effect of extraneous confounding variables fields were selected as target habitats because soil properties in agricultural fields are more homogenous and the water regime more stable than anywhere else.

These traps were set for two weeks during the main peaks in carrion beetle activity (season): 17-31 May 2009 (spring), 5-19 July 2009 (summer) and 13-27 September 2009 (autumn), based on the data on activity in Růžička (1994). A complete sample consists of the contents of each trap collected over a period of two weeks. The samples were stored separately and included in the analysis only if the trap and bait was not disturbed or damaged by animals, humans or weather conditions.

Adult carrion beetles were identified to species level following Růžička \& Schneider (2004) and stored in 75\% ethanol. Selected voucher specimens were dry mounted and are deposited in the author's collection.

\section{Data analysis}

Detrended correspondence analysis (DCA) was performed on the species abundance data for each locality to determine the length of the gradient and detect whether some species are covarying.

To test the effect of environmental factors on carrion beetles we decided to use partial canonical correspondence analysis (CCA) with a randomized block design in which the blocks were defined by covariates (season and region). We chose CCA over redundancy analysis because DCA indicated that the length of the gradient is more than 3.7 SD units long and, therefore, we had to use a unimodal type of analysis. Bonferroni correction was applied to adjust for multiple comparisons of the following environmental factors: soil type (chernozem and fluvisol), climatic region (warm - T2, very warm - T4 and mildly warm - MT10), land cover $=$ crop (Brassica napus, Beta vulgaris, Carthamus tinctorius, Glycine max, Heliantus annus, Hordeum vulgare, Phacelia tanacetifolia, Triticum aestivum and Zea mays) and their interac- 


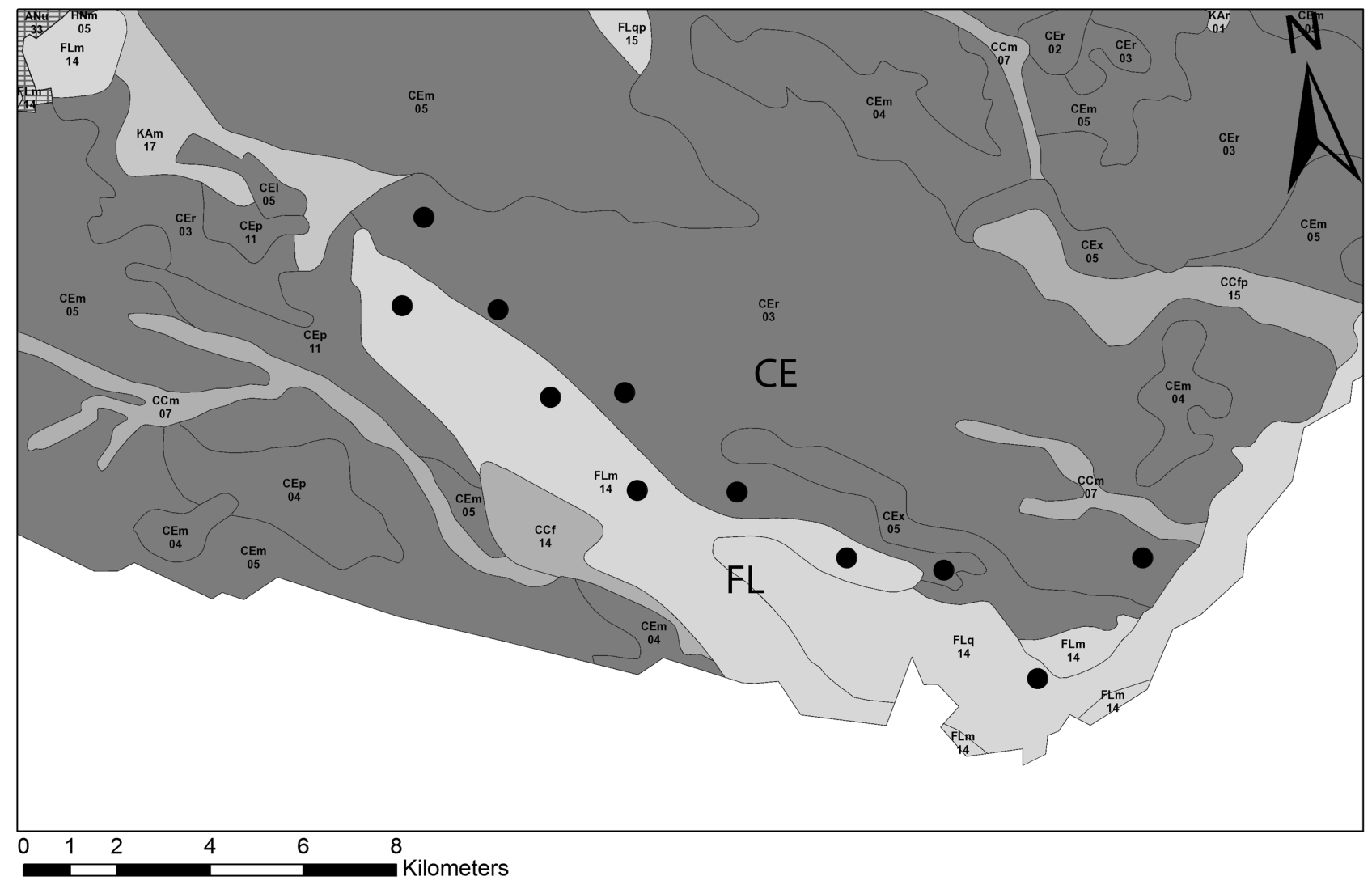

Fig. 2. Distribution of the localities (black dots) based on soil type $(\mathrm{CE}=$ chernozem; $\mathrm{FL}=$ fluvisol) in the South Moravian region (Cenia, 2015).

tions. Influence of regions was filtered out by using it as a covariate, because we were not interested in that effect.

The diversity of carrion beetles at each location and geographically related region was measured by calculating the Brillouin biodiversity index $[\mathrm{H}=1 / \mathrm{N} \cdot \ln (\mathrm{N} ! / \mathrm{n} 1 ! \mathrm{n} 2 ! \ldots \mathrm{ns} !)]$ from the total abundance data across all sampling periods (three times two weeks), where $\mathrm{N}$ is the total number of individuals caught at a location and $\mathrm{n} 1, \mathrm{n} 2 \ldots \mathrm{ns}$ are the numbers of individuals of all car- rion beetles collected at the location (Pielou, 1975). We used this index, because it does not assume randomness of sampling and equal attractiveness of traps as does the commonly used Shannon index (see Magurran, 2004). The number of specimens at each location was averaged over the number of samples, because they differed between locations due to unavoidable adverse events (flooding by rain or destruction of traps).

TABLE 1. Total and mean number of carrion beetles specimens per trap on chernozem and fluvisol. Species marked as NA were excluded from statistical evaluation because of underrepresentation.

\begin{tabular}{|c|c|c|c|c|c|c|c|}
\hline \multirow{2}{*}{ Species } & \multirow{2}{*}{$\begin{array}{c}\text { All } \\
\text { Total }\end{array}$} & \multicolumn{2}{|c|}{ Chernozem } & \multicolumn{2}{|c|}{ Fluvisol } & \multicolumn{2}{|c|}{ Wilcoxon rank-sum test } \\
\hline & & Total & Per trap & Total & Per trap & $\mathrm{W}$ & p-value \\
\hline Nicrophorus antennatus (Reitter) & 29 & 28 & 0.1407 & 1 & 0.0041 & 28118.5 & $<0.001^{*}$ \\
\hline Nicrophorus germanicus (Linnaeus) & 216 & 150 & 0.7538 & 66 & 0.2694 & 25946.5 & $0.0288^{*}$ \\
\hline Nicrophorus humator (Gleditsch) & 32 & 4 & 0.0201 & 28 & 0.1143 & 23152.5 & $0.0047 *$ \\
\hline Nicrophorus interruptus (Stephens) & 909 & 601 & 3.02 & 308 & 1.257 & 26693 & $0.0297 *$ \\
\hline Nicrophorus investigator (Zetterstedt) & 7 & 5 & 0.0251 & 2 & 0.0082 & NA & NA \\
\hline Nicrophorus sepultor (Charpentier) & 1827 & 1431 & 7.191 & 396 & 1.616 & 31962 & $<0.001 *$ \\
\hline Nicrophorus vespillo (Linnaeus) & 6332 & 3029 & 15.22 & 3303 & 13.48 & 26100 & 0.0997 \\
\hline Nicrophorus vespilloides (Herbst) & 6 & 3 & 0.0151 & 3 & 0.0122 & NA & NA \\
\hline Oiceoptoma thoracicum (Linnaeus) & 6 & 3 & 0.0151 & 3 & 0.0122 & NA & NA \\
\hline Phosphuga atrata atrata (Linnaeus) & 1 & 0 & 0 & 1 & 0.0041 & NA & NA \\
\hline Silpha carinata (Herbst) & 104 & 37 & 0.1859 & 67 & 0.2735 & 23564 & 0.859 \\
\hline Silpha obscura obscura (Linnaeus) & 5192 & 4704 & 23.64 & 488 & 1.992 & 31132 & $<0.001^{*}$ \\
\hline Silpha tristis (Illiger) & 136 & 68 & 0.3417 & 68 & 0.2776 & 24278 & 0.5488 \\
\hline Thanatophilus rugosus (Linnaeus) & 1268 & 615 & 3.09 & 653 & 2.665 & 25835.5 & 0.1266 \\
\hline Thanatophilus sinuatus (Fabricius) & 27791 & 13644 & 68.56 & 14147 & 57.74 & 28514.5 & $<0.001 *$ \\
\hline
\end{tabular}

* Significant result of the one-sided Wilcoxon rank-sum test, chernozem vs. fluvisol. 


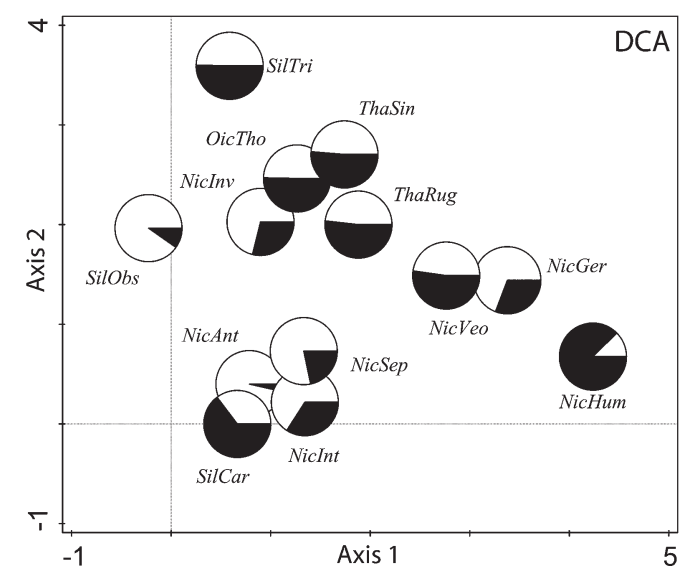

Fig. 3. Unconstrained DCA of all species (NicAnt $=N$. antennatus; $\mathrm{NicGer}=N$. germanicus $; \mathrm{NicHum}=N$. humator $; \mathrm{NicInt}=$ $N$. interruptus; NicInv $=N$. investigator $; \mathrm{NicSep}=N$. sepultor; $\mathrm{NicVeo}=N$. vespillo $; \mathrm{NicVes}=N$. vespilloides $;$ OicTho $=O$. thoracicum; SilCar $=S$. carinata $;$ SilObs $=S$. obscura obscura $;$ SilTri $=S$. tristis $;$ ThaRug $=T$. rugosus $;$ ThaSin $=T$. sinuatus $)$ with their percentage abundance in areas with different types of soil (chernozem - white, fluvisol - black) illustrated by pie charts.

We used the Wilcoxon rank-sum test with continuity correction to test our hypothesis that abundance of carrion beetles differs in the areas with the two different types of soil. This hypothesis was tested for the whole taxonomic family Silphidae and for each individual species. We chose this nonparametric test because the data were not normally distributed. We also tested the effect of soil type on the Brillouin biodiversity index using Welch's t-test for two samples.

The significance level was set at 5\%. Data management and all analysis was carried out using the Canoco 5 and R statistical programs (ter Braak \& Šmilauer, 2012; R Core Team, 2014).

\section{RESULTS}

In total, we obtained 444 samples of silphid communities from 39 different locations (18 on chernozem and 21 on fluvisol soils), the rest was destroyed or did not contain any carrion beetles. In these samples there were 43,856 specimens of 15 carrion beetle species (see Table 1). Three of them are on the Czech Red List of Invertebrates. Nicrophorus antennatus (Reitter) and N. germanicus (Linnaeus) are considered to be Endangered and N. sepultor (Charpentier) Nearly Endangered (Růžička, 2005).

The whole dataset was dominated by Thanatophilus sinuatus (Fabricius) ( $>63 \%$ of the total catch). This species was also dominant in spring $(>73 \%)$ and summer $(>58 \%)$ but not in autumn (12\%) when it was the third most abundant after Nicrophorus vespillo (Linnaeus) (>55\%) and Thanatophilus rugosus (Linnaeus) $(>15 \%)$.

DCA showed that species did not cluster according to their percentage abundance on either chernozem or fluvisol soils (see Fig. 3). This indicates that other environmental factors could also be involved in determining their occurrence. We tested all the environmental factors included in the CCA analysis, and manual forward selection indicated the following were significant: soil type [chernozem $\left(\mathrm{p}_{\text {adj }}\right.$ $=0.038)$ and fluvisol $\left.\left(\mathrm{p}_{\mathrm{adj}}=0.038\right)\right]$ and three crops $[Z e a$

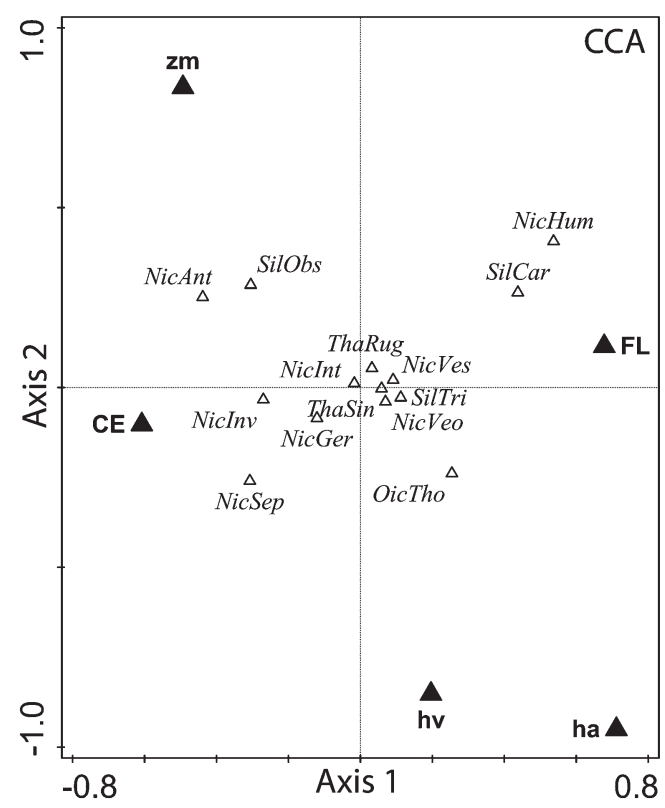

Fig. 4. Partial CCA ordination diagram with carrion beetles and statistically significant environmental variables $(\mathrm{CE}-$ chernozem, FL - fluvisol, zm - Zea mays, hv - Hordeum vulgare, ha - Heliantus annus).

mays $\left(\mathrm{p}_{\mathrm{adj}}=0.038\right)$, Hordeum vulgare $\left(\mathrm{p}_{\mathrm{adj}}=0.038\right)$ and Heliantus annus $\left.\left(\mathrm{p}_{\mathrm{adj}}=0.038\right)\right]$ (see Fig. 4). The remaining factors appeared to have no significant effect on the composition of the carrion beetles recorded in this study (climatic region (T4, T2 and MT10) and other crops [Brassica napus, Beta vulgaris, Carthamus tinctorius, Glycine max, Phacelia tanacetifolia and Triticum aestivum)].

These finding led us to test the effect of soil on the biodiversity and abundance of carrion beetles. The Brillouin biodiversity index ranged from 0.188 to 1.271 between localities, but there was not a significant association $(\mathrm{t}=$ $1.747, \mathrm{p}=0.09$ ) between this index and soil type (mean values of the Brillouin index: chernozem $=0.835$ and fluvisol $=0.692$ ).

The carrion beetles as a group were significantly more abundant in areas with a chernozem soil, where the median abundance was 62 ( $\mathrm{SD}= \pm 157.38)$, than on fluvisol soils, where the median abundance was $37(\mathrm{SD}= \pm 110.867)$ $(\mathrm{W}=28677.5, \mathrm{p}>0.001)$. At the species level there were significantly higher numbers of specimens of the following species in areas with chernozem soils: Nicrophorus antennatus $(\mathrm{W}=26118.5, \mathrm{p}>0.001), N$. germanicus $(\mathrm{W}$ $=25946.5, \mathrm{p}=0.029), N$. interruptus (Stephens) $(\mathrm{W}=$ $26693, \mathrm{p}=0.03)$, N. sepultor $(\mathrm{W}=31962, \mathrm{p}>0.001)$, Silpha obscura obscura (Linnaeus) $(\mathrm{W}=31132, \mathrm{p}>0.001)$ and $T$. sinuatus $(\mathrm{W}=28514.5, \mathrm{p}=0.001)$. Only in the case of $N$. humator (Gleditsch) $(\mathrm{W}=23152.5, \mathrm{p}=0.005)$ were significantly more caught in areas with fluvisol soils. For the rest of the species we did not find any significant association between their abundance and the soil types studied, although we had to exclude some species from the statistical evaluation because they were underrepresented, namely: N. investigator (Zetterstedt) $(\mathrm{n}=7), N$. vespilloides 


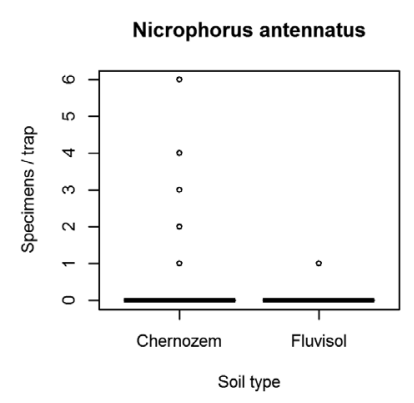

Nicrophorus investigator

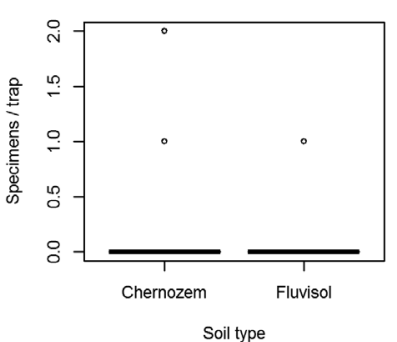

Oiceoptoma thoracicum

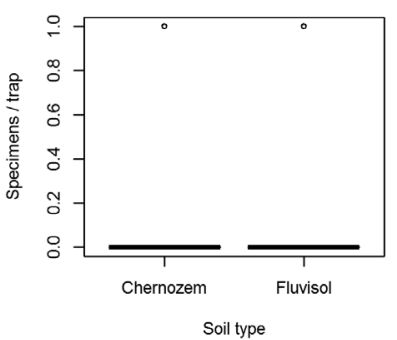

Silpha tristis

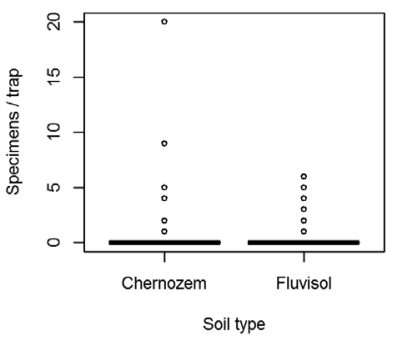

Nicrophorus germanicus

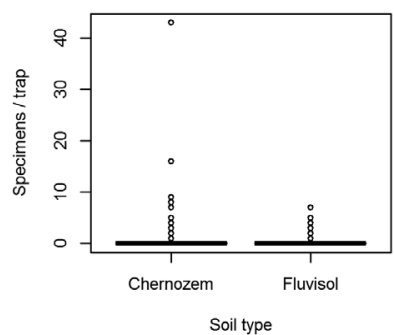

Nicrophorus sepultor

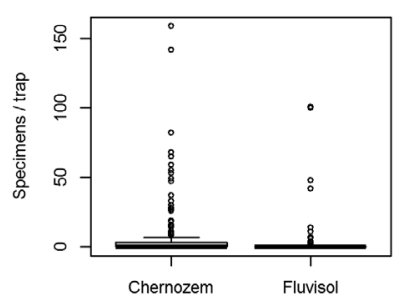

Soil type

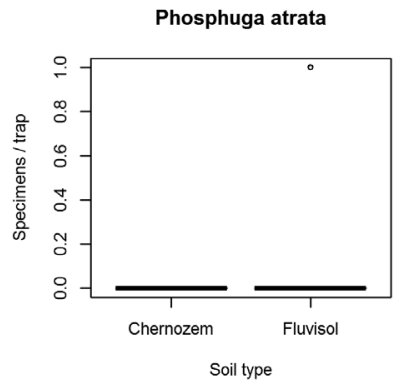

Thanatophilus rugosus

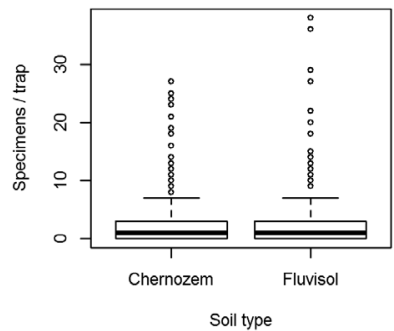

Nicrophorus humator
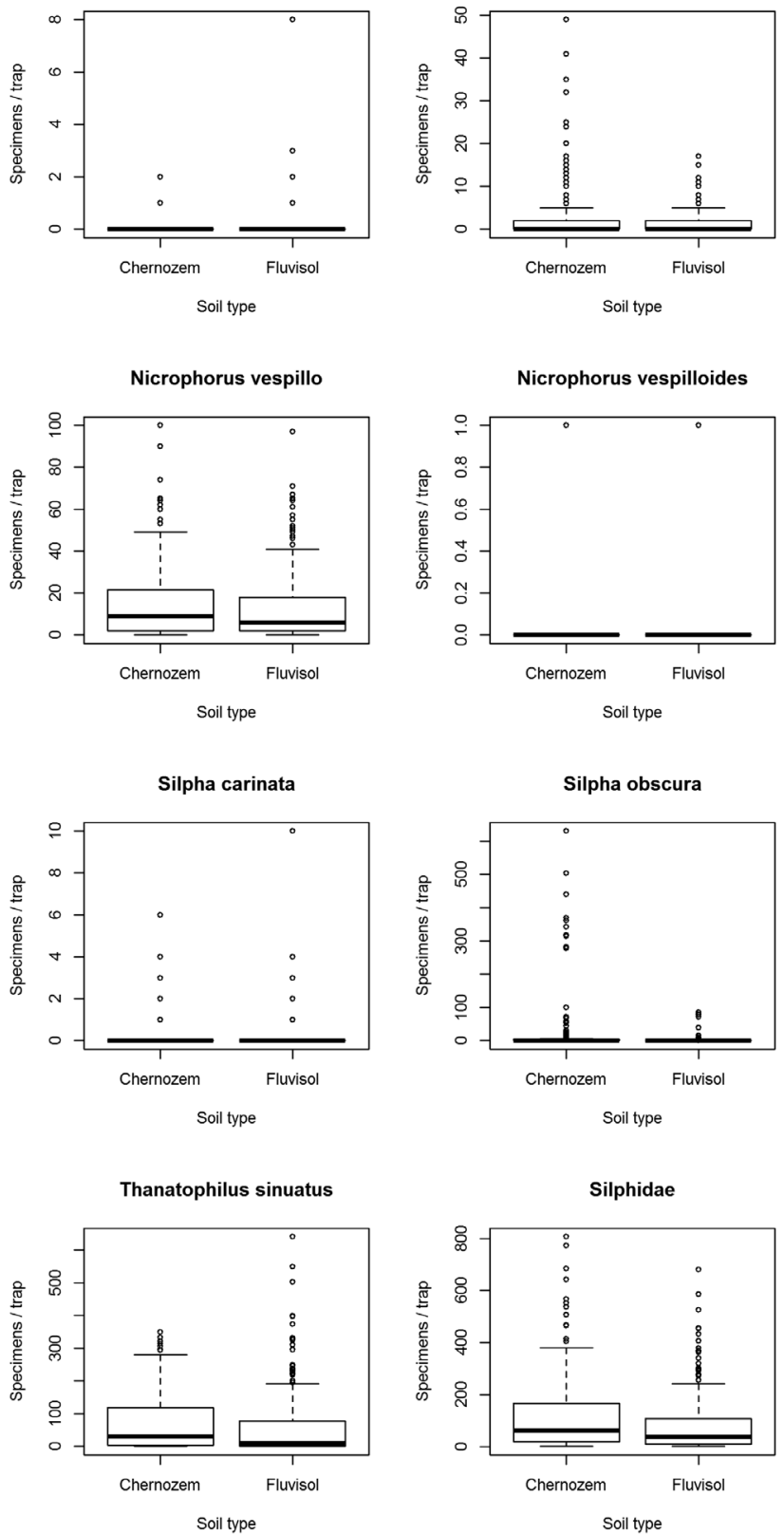

Nicrophorus interruptus

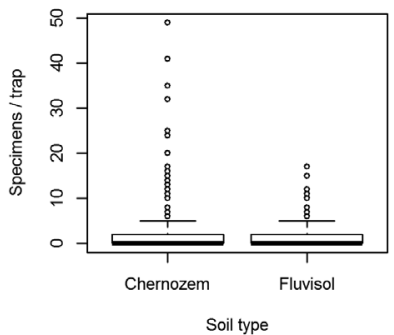

Nicrophorus vespilloide

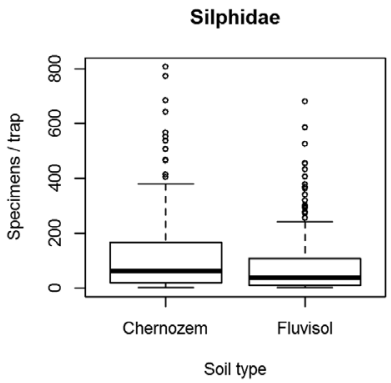

Fig. 5. Box plots of all the carrion beetles recorded in the areas with the two types of soil. The thick horizontal lines within the boxes indicate median values. The upper and lower boxes indicate the 75th and 25 th percentiles, respectively. Whiskers indicate the values within the 1.5 interquartile ranges. Small circles are outliers.

(Herbst) $(\mathrm{n}=6)$, Oiceoptoma thoracicum (Linnaeus) $(\mathrm{n}=$ 8 ) and Phosphuga atrata atrata (Linnaeus) $(\mathrm{n}=1)$. For an overview of the results, see Fig. 5 and Table 1.

\section{DISCUSSION}

During the field work we captured and identified 15 species of carrion beetles. Three of which are currently considered as rare and are on the Czech Red List of Invertebrates as Endangered ( $N$. antennatus and $N$. germanicus) or Nearly Endangered (N. sepultor) (Růžička, 2005). The last ecological studies on these species in Europe were done almost 50 years ago when they were probably much more common (Novák, 1966; Petruška, 1968). These spe- cies deserve much more attention, because they could play a major role in nature conservation as bio-indicators or umbrella species (see Guarisco, 1997; Holloway \& Schnell, 1997; Walker \& Hoback, 2007; Creighton et al., 2009; Crawford \& Hoagland, 2010; Jurzenski et al., 2014).

The most frequent species was T. sinuatus, whose dominance was overshadowed by $N$. vespillo and T. rugosus, but only in autumn. All these species seem to be very common in open landscape habitats and our findings confirm the earlier observations of Novák $(1962,1965,1966)$ and Petruška (1964).

T. sinuatus and T. rugosus are considered to be co-occurring species without spatially or temporally differentiated 
niches (Novák, 1966). The higher abundance of T. rugosus in autumn samples could indicate a temporal niche differentiation.

Some of the carrion beetles caught are considered to be forest species ( $N$. humator, $N$. investigator, $N$. vespilloides and $O$. thoracicum) by several authors (e.g. Růžička, 1994; Kočárek \& Benko, 1997). Although the traps were not set in forested areas, our observations are in line with their findings, because few of these species were caught in this study (in total 32, 7,6 and 6 specimens, respectively). The more frequent occurrence of $N$. humator was probably due to the greater flight activity of this large and common beetle.

CCA analysis revealed that the factors that are significantly associated with the species composition are both soil types (chernozem and fluvisol) and three crops (Zea mays, Hordeum vulgare and Heliantus annus). As depicted in Fig. 4 the positions of these factors are roughly orthogonal, with the exception of $H$. vulgare and $H$. annus, therefore they are probably unrelated.

The association between the abundance of the carrion beetles and these crops is very interesting. We think that it could be due to the microclimatic conditions in fields with these crops. Based on our experience, Z. mays provides a much more humid and cooler environment than $H$. vulgare and $H$. annus. Further study is needed to reveal causality.

We were able to show that the abundance of seven of the carrion beetles ( $N$. antennatus, $N$. germanicus, $N$. humator, $N$. interruptus, N. sepultor, Silpha obscura obscura and $T$. sinuatus) differed significantly in areas with chernozem and fluvisol soils, and therefore soil type is an important factor in determining the occurrence of these carrion beetles. Our findings are supported by the results of the CCA analysis and Wilcoxon rank-sum tests.

This association is assumed by many authors, but only for beetles of the subgenus Nicrophorus (e.g. Pukowski, 1933; Paulian, 1946; Theodorides \& Heerdt, 1952; Novák, 1961, 1962). Heretofore, this phenomenon was empirically proven only for North American species (Muths, 1991; Bishop et al., 2002; Looney et al., 2009), where the association of beetles of the subfamily Silphinae with a particular soil was previously reported by Bishop et al. (2002).

All these findings raise an important question as to what mechanisms drive this phenomenon. Muths (1991) has shown that burying beetles are able to distinguish among different types of soil and choose the best substrate for digging in the laboratory. This experiment was conducted at a small scale (an area with a diameter of $1.5 \mathrm{~m}$ ) and it is reasonable to think that this type of response occurs only during microhabitat selection. Thus, it does not answer our question. Our goal was to determine if the type of soil could be important in habitat selection. Looney et al. (2009) offers three possible explanations. Beetles are either simply more abundant in areas with a particular type of soil, or they preferentially colonize, or they are more competitive in such areas. From our point of view the last option is the most likely for the following reasons.
It is likely that one of the main factors influencing long range habitat selection by carrion beetles is the presence of food (carrion) (Kalinová et al., 2009). The greater abundance of these beetles in areas with particular types of soil (chernozem or fluvisol in our case) could be caused indirectly.

Although burying beetles are good fliers and can cover long distances they mostly choose to stay close to their original locations (e.g. Nicrophorus americanus, which is a relatively large and robust beetle, is capable of flying as far as $7.41 \mathrm{~km}$ in a single night, but more typically travels less than $1.6 \mathrm{~km} /$ night) (Jurzenski et al., 2011). Limited mobility coupled with adaptation to local conditions could cause the observed spatial structure rather than individual habitat choice (preferential colonization). This is also in line with general local adaptation hypotheses (Alstad, 1998).

The same reasons might account for our finding in the case of $T$. sinuatus, because it has functional wings (Ikeda et al., 2008), but only a short flight range (Petruška, 1964). Therefore, it has a very similar lifestyle to the burying beetles studied: $N$. antennatus, $N$. germanicus, $N$. humator, $N$. interruptus, $N$. investigator, $N$. sepultor, $N$. vespillo and $N$. vespilloides. This hypothesis is supported by the fact that all these species were recorded in areas with both of the different types of soil and often in large numbers, so they are not closely associated with a particular type of soil (see Table 1).

The biology of Silpha obscura obscura is not well known. There is little known about the diet and flight ability of the species in the genus Silpha (Ikeda et al., 2007). There is also a strong possibility that this species is not strictly necrophagous. Its preference for areas with a chernozem soil is surprising in this case, but it could be due the spatial structure of the population, which is driven by an adaptation to chernozem soil.

Loess loams are proposed as the preferred soils of many species of burying beetles ( $N$. antennatus, $N$. germanicus, $N$. interruptus, $N$. vespillo and $N$. sepultor), but according to Novák (1962) N. vestigator prefers sandy soils. This species unfortunately was not recorded in our study despite the fact that we set traps close to locations where it was often recorded by collectors in the past. It is possible that we missed the population peaks of this rare species. Future studies on this species should focus on earlier months in the year (April-May), when it could be more abundant (Novák, 1962; Šustek, 1981).

Our findings are limited to two types of soil (chernozem and fluvisol) and can be extended only to similar types of soil (e.g. Phaeozem and haplic Luvisol). It is also possible that the abundances of the species studied are different throughout their distribution area, as pointed out by Scott (1998).

This study has revealed more about the distribution and ecology of European carrion beetles, especially the preference of three endangered species ( $N$. antennatus, $N$. germanicus and $N$. sepultor) for areas with chernozem soils (see also Jakubec \& Růžička, 2012). Our finding that the 
preferences of some species of carrion beetles are possibly determined by an adaptation to particular types of soil is crucial for the effective conservation of these species, which is currently not a topical issue in the Czech Republic and Europe generally. These beetles are charismatic and could become a widely accepted flagship species for stakeholders and policymakers, as indicated by the public interest in and the vast number of studies on the American burying beetle (N. americanus) (e.g., Anderson, 1982b; Lomolino et al., 1995; Amaral et al., 1997; Crawford \& Hoagland, 2010).

ACKNOWLEDGEMENTS. We would like to thank M. Šálek for his help with the experimental design; J. Vojar, F. Harabiš, J. Knappová and M. Knapp for their assistance with the statistical analysis; and especially L. Lvová (Chlumecká), H. Šifrová and K. Štefúnová for their hard work during the sampling, identification and preparation of the beetles. This project was supported by the Internal Grant Agency of the Faculty of Environmental Sciences, CULS Prague (no. 421101312313020144228).

\section{REFERENCES}

Alstad D. 1998: Population structure and conundrum of local adaptation. In Mopper S. \& Strauss S.Y. (eds): Genetic Structure and Local Adaptation in Natural Insect Populations: Effects of Ecology, Life History and Behavior. Springer, Dordrecht, pp. 3-21.

Amaral M., Kozol A. \& French T. 1997: Conservation status and reintroduction of the endangered American burying beetle. Northeast. Natur. 4: 121-132.

ANDERSON R.S. 1982a: Resource partitioning in carrion beetle (Coleoptera: Silphidae) fauna of southern Ontario: ecological and evolutionary considerations. - Can. J. Zool. 60: 13141325 .

ANDERSON R.S. 1982b: On the decreasing abundance of Nicrophorus americanus Olivier (Coleoptera: Silphidae) in Eastern North America. - Coleopt. Bull. 36: 362-365.

Anderson R.S. \& Peck S.B. 1985: The Insects and Arachnids of Canada, Part 13: The Carrion Beetles of Canada and Alaska (Coleoptera: Silphidae and Agyrtidae). Agriculture Canada, Ottawa, $121 \mathrm{pp}$.

ARCHER M.S. 2003: Annual variation in arrival and departure times of carrion insects at carcasses: implications for succession studies in forensic entomology. - Austral. J. Zool. 51: 569-576.

Bishop A.A., Hoback W.W., Albrecht M. \& SkinNer K.M. 2002: A comparison of an ecological model and GIS spatial analysis to describe niche partitioning amongst carrion beetles in $\mathrm{Ne}$ braska. - Transact. GIS 6: 457-470.

BraAK C.J.F. TER \& ŠMILAUER P. 2012: Canoco Reference Manual and User's Guide Software for Ordination, Ver. 5.0. Microcomputer Power, Ithaca, $496 \mathrm{pp}$.

CENIA 2008: Czech National Geoportal. http:/geoportal.gov.cz [accessed 2008].

Cenia 2015: Czech National Geoportal. http:/geoportal.gov.cz [accessed 2015].

Crawford P.H.C. \& Hoagland B.W. 2010: Using species distribution models to guide conservation at the state level: the endangered American burying beetle (Nicrophorus americanus) in Oklahoma. - J. Insect Conserv. 14: 511-521.

Creighton J.C., Vaughn C.C. \& Chapman B.R. 1993: Habitat preference of the endangered American burying beetle (Nicrophorus americanus) in Oklahoma. - Southw. Natur. 38: 275277.
Creighton J.C., Bastarache R., Lomolino M.V. \& Belk M.C. 2009: Effect of forest removal on the abundance of the endangered American burying beetle, Nicrophorus americanus (Coleoptera: Silphidae). - J. Insect Conserv. 13: 37-43.

ESRI 2008: ArcMap 9.2. ESRI. Environmental Systems Research Institute, Redlands, CA.

Goff M.L. 2009: Forensic entomology. In Resh V.H. \& Cardé R.T. (eds): Encyclopedia of Insects. Elsevier, London, pp. 381-386.

Grebennikov V.V. \& Newton A.F. 2012: Detecting the basal dichotomies in the monophylum of carrion and rove beetles (Insecta: Coleoptera: Silphidae and Staphylinidae) with emphasis on the Oxyteline group of subfamilies. - Arthr. Syst. Phylog. 70: $133-165$.

GuARISCO H. 1997: Discovery of the federally endangered American burying beetle (Nicrophorus americanus) in the Chautauqua Hills of Southeastern Kansas. - Trans. Kans. Acad. Sci. 100: $116-122$.

Hocking M.D., Darimont C.T., Christie K.S. \& Reimchen T.E. 2007: Niche variation in burying beetles (Nicrophorus spp.) associated with marine and terrestrial carrion. - Can. J. Zool. 85: $437-442$.

Holloway A.K. \& SCHNeLl G.D. 1997: Relationsip between numbers of the endangered American burying beetle Nicrophorus americanus Olivier (Coleoptera: Silphidae) and available food resources. - Biol. Conserv. 81: 145-152.

Ikeda H., Kagaya T., Kubota K. \& Abe T. 2007: Flight capabilities and feeding habits of silphine beetles: are flightless species really "carrion beetles"? - Ecol. Res. 22: 237-241.

Ikeda H., Kagaya T., Kubota K. \& Abe T. 2008: Evolutionary relationships among food habit, loss of flight, and reproductive traits: life-history evolution in the Silphinae (Coleoptera: Silphidae). - Evolution 62: 2065-2079.

JAKUBEC P. \& RŮŽIČKA J. 2012: Distribution of open landscape carrion beetles (Coleoptera: Silphidae) in selected lowlands of the Czech Republic. — Klapalekiana 48: 169-189.

Jurzenski J., Snethen D.G., Brust M.L. \& Hoback W.W. 2011: New records of carrion beetles in Nebraska reveal increased presence of the American burying beetle, Nicrophorus americanus Olivier (Coleoptera: Silphidae). - Great Plains Res. 21: 131-143.

Jurzenski J.D., Jorgensen C.F., Bishop A., Grosse R., Riens J. \& Hоваск W.W. 2014: Identifying priority conservation areas for the American burying beetle, Nicrophorus americanus (Coleoptera: Silphidae), a habitat generalist. - Syst. Biodiv. 12: 149-162.

Kalinová B., Podskalská H., RŮžıčKa J. \& Hoskovec M. 2009: Irresistible bouquet of death - how are burying beetles (Coleoptera: Silphidae: Nicrophorus) attracted by carcasses. Naturwissenschaften 96: 889-899.

KoČÁREK P. 2001: Diurnal activity rhythms and niche differentiation in a carrion beetle assemblage (Coleoptera: Silphidae) in Opava, the Czech Republic. — Biol. Rhythm Res. 32: 431-438.

KoČÁREK P. \& BENKo K. 1997: The occurence and seasonal activity of Silphidae in Hlučín region (Silesia, Czech Republic). Čas. Slez. Muz. Opava 46: 173-179.

LiNGAFELTER S.W. 1995: Diversity, habitat preferences, and seasonality of Kansas carrion beetles (Coleoptera: Silphidae ). J. Kans. Entomol. Soc. 68: 214-223.

Lomolino M.V. \& Creighton J.C. 1996: Habitat selection, breeding success and conservation of the endangered American burying beetle Nicrophorus americanus. - Biol. Conserv. 77: 235-241.

Lomolino M.V., Creighton J.C., Schnell G.D. \& Certain D.L. 1995: Ecology and conservation of the endangered American 
burying beetle (Nicrophorus americanus). - Conserv. Biol. 9 605-614.

Looney C., Caldwell B.T. \& Eigenbrode S.D. 2009: When the prairie varies: the importance of site characteristics for strategising insect conservation. - Insect Conserv. Divers. 2: 243-250.

Magurran A.E. 2004: Measuring Biological Diversity. Blackwell, Malden, Oxford, Carleton, 215 pp.

Mullins P.L., Riley E.G. \& Oswald J.D. 2013: Identification, distribution, and adult phenology of the carrion beetles (Coleoptera: Silphidae) of Texas. - Zootaxa 3666: 221-251.

Muths E.L. 1991: Substrate discrimination in burying beetles, Nicrophorus orbicollis (Coleoptera: Silphidae). — J. Kans. Entomol. Soc. 64: 447-450.

NovÁk B. 1961: Saisonmässiges Vorkomenn von Totengräbern in Feldbiozönosen (Col. Silphidae). — Acta Univ. Palack. Olomuc. Fac. Rer. Natur. 6: 45-114.

NovÁk B. 1962: Ein Beitrag zur Faunistik und Ökologie der Totengräber (Col. Silphidae). - Acta Univ. Palack. Olomuc. Fac. Rer. Natur. 11: 263-300.

NovÁk B. 1965: Zur Faunistik und Ökologie der Totengräber in den Feldbiotopen von Haná (Col. Silphidae). - Acta Univ. Palack. Olomuc. Fac. Rer. Natur. 19: 121-151.

NovÁk B. 1966: Populationsdynamik der Silphini (Coleoptera). - Acta Univ. Palack. Olomuc. Fac. Rer. Natur. 22: 129-151.

Paulian R. 1946: Essai de bionomie quantitative sur les nécrophores. - Rev. Fr. Entomol. 13: 93-98.

Peck S.B. \& Anderson R.S. 1985a: Taxonomy, phylogeny and biogeography of the carrion beetles of Latin America (Coleoptera: Silphidae). — Quaest. Entomol. 21: 247-317.

PecK S.B. \& Anderson R.S. 1985b: Seasonal activity and habitat associations of adult small carrion beetles in southern Ontario (Coleoptera: Leiodidae: Cholevinae). - Coleopt. Bull. 39: 347-353.

PetrušKa F. 1964: Beitrag zur Bewegungsaktivität einiger Aaskäfer-Arten (Col. Silphidae et Histeridae). - Acta Univ. Palack. Olomuc. Fac. Rer. Natur. 16: 159-187.

PetrušKa F. 1968: The carrion-beetles as a component part of the insects fauna of the fields in the Uničov plain. - Acta Univ. Palack. Olomuc. Fac. Rer. Natur. 28: 159-187.

Pielou E.C. 1975: Ecological Diversity. Wiley-Interscience, New York, $165 \mathrm{pp}$.

Pukowski E. 1933: Oekologische Untersuchungen an Necrophorus F. - Z. Morphol. Oekol. Tiere 27: 518-186.
R CoRe TeAm 2014: R: A language and Environment for Statistical Computing. R Foundation for Statistical Computing, Vienna.

RŮŽIČKA J. 1994: Seasonal activity and habitat associations of Silphidae and Leiodidae: Cholevinae (Coleoptera) in central Bohemia. - Acta Soc. Zool. Bohem. 58: 67-78.

RŮŽIČKA J. 2005: Silphidae (carrion beetles). In Farkač J., Král D. \& Škorpík M. (eds): Red List of Threatened Species in the Czech Republic. Invertebrates. Agentura ochrany prírody a krajiny ČR, Prague, pp. 429-430 [in Czech].

RŮŽIČKA J. 2007: Beetles (Coleoptera) in rock debris of Komáří vrch hill, catastre of Nová Ves near Kraslice. In Hejkal J., Havalová A. \& Michálek J. (eds): Př́roda Kraslicka 1. [Nature of Kraslice Region 1.] Jan Farkač, Prague, pp. 83-102 [in Czech].

RŮŽIČKA J. \& SCHNeIDER J. 2004: Silphidae. In Löbl I. \& Smetana A. (eds): Catalogue of Palaearctic Coleoptera. Vol. 2. Apollo Books, Stenstrup, pp. 229-237.

ScotT M.P. 1998: The ecology and behavior of burying beetles. - Annu. Rev. Entomol. 43: 595-618.

Sikes D. 2005: Silphidae Latreille, 1807. In Beutel R.G. \& Leschen R.A.B. (eds): Handbook of Zoology, Vol. IV: Arthropoda: Insecta, Part 38: Coleoptera, Beetles. Vol. 1: Morphology and Systematics (Archostemata, Adephaga, Myxophaga, Polyphaga partim). Walter de Gruyter, Berlin, pp. 288-296.

SIKES D. 2008: Carrion beetles (Coleoptera: Silphidae). In Capinera J.L. (ed.): Encyclopedia of Entomology. Vol. 1A-C. Springer, Berlin, pp. 749-758.

Sikes D.S. \& Venables C. 2013: Molecular phylogeny of the burying beetles (Coleoptera: Silphidae: Nicrophorinae). Mol. Phylogen. Evol. 69: 552-565.

Šustek Z. 1981: Keys to identification of insects 2: Carrion beetles of Czechoslovakia (Coleoptera: Silphidae). - Zpr. $\breve{s}$. Spol. Entomol. ¿̌SAV 2: 1-47.

Theodorides J. \& HeERdT P.F. 1952: Nouvelles recherches écologiques sur les nécrophores (Coleoptera Silphidae); comparaison des résultats du terrain avec ceux du laboratoire (thermopreferendum at hygropreferendum). - Physiol. Compar. Oecol. 2: 297-309.

WALKer T.L. \& Hoback W.W. 2007: Effects of invasive eastern redcedar on capture rates of Nicrophorus americanus and other Silphidae. —Environ. Entomol. 36: 297-307.

Received February 25, 2015; revised and accepted June 8, 2015 Prepublished online July 8, 2015 